\title{
Effects of anionic polyacrylamide on maize growth: a short term ${ }^{14} \mathrm{C}$ labeling study
}

\author{
Liang Wu • Yong Sik Ok • Xing Liang Xu • \\ Yakov Kuzyakov
}

Received: 18 February 2011 / Accepted: 8 July 2011 / Published online: 30 July 2011

(C) The Author(s) 2011. This article is published with open access at Springerlink.com

\begin{abstract}
Aims Various anionic polyacrylamide polymers (PAMs) are frequently used to improve soil properties and reduce erosion. However, the effects of their application on plant growth remain unclear.

Methods Aggregate-free loess with high water holding capacity was used as growing substrate to test the effects of two rates (10 and $\left.40 \mathrm{~kg} \mathrm{ha}^{-1}\right)$ of a linear PAM on the growth of maize (Zea maize L.) for a period up
\end{abstract}

Responsible Editor: Zucong Cai.

L. Wu $\cdot$ X. L. Xu • Y. Kuzyakov $(\bowtie)$

Key Laboratory of Ecosystem Network Observation and Modeling, Institute of Geographical Sciences and Natural Resources Research,

Chinese Academy of Sciences,

Beijing 100101, China

e-mail: kuzyakov@gwdg.de

L. Wu $\cdot$ Y. Kuzyakov

Department of Soil Science of Temperate Ecosystems,

University of Göttingen,

Büsgenweg 2,

37077 Göttingen, Germany

L. Wu

Graduate School of Chinese Academy of Sciences,

Beijing 100049, China

Y. S. Ok

Department of Biological Environment,

Kangwon National University,

Chuncheon 200-701, South Korea to one month. The PAM effects were evaluated at three levels of soil water content (SWC) and three plant ages, based on water consumption, shoot and root biomass, as well as allocation of recently assimilated $\mathrm{C}$ in plants and soil using ${ }^{14} \mathrm{C}$ labeling. Results Both SWC and maize age significantly affected water consumption, biomass accumulation, and ${ }^{14} \mathrm{C}$ allocation in plant parts and soil. Even though consistent increases in plant biomass and total assimilated ${ }^{14} \mathrm{C}$ were observed, the effects of PAM application were insignificant on either of these variables.

Conclusions The effects of PAM application were directly connected to soil rather than to maize, and could be masked by the non-structural loess. The effects tended to be age and soil-moisture specific, and were modulated by the rhizodeposition processes. The possible mechanisms of PAM application on plant growth were also discussed.

Keywords PAM · Soil aggregates · Plant activity

${ }^{14} \mathrm{C}$ labeling $\cdot$ Soil moisture $\cdot$ Rhizodeposition

$\begin{array}{ll}\text { Abbreviations } \\ \text { PAM } & \text { Polyacrylamide polymer } \\ \text { DOC } & \text { Dissolved organic matter } \\ \text { SWC } & \text { Soil water content } \\ \text { WHC } & \text { Water holding capacity } \\ \text { SE } & \text { Standard error } \\ \text { ANOVA } & \text { Analysis of variance } \\ \text { HSD } & \text { Tukey's Honest Significant Differences }\end{array}$




\section{Introduction}

Synthetic polymeric conditioners have been used to improve the physical, chemical, and biological properties of soils since the 1950s (Hedrick and Mowry 1952; Martin 1953; Sherwood and Engibous 1953; Sojka et al. 2007). Being the most popular polymeric conditioners, the anionic polyacrylamide polymers (PAMs) are water-soluble, have high molecular weight and low toxicity, with their moderate negative-charged chains stabilize soil aggregates by flocculating clay particles (Sojka et al. 2007). Modified crop soil management with PAM has shown great promise for soil erosion, water conservation and greenhouse gas mitigation (via the reduction use of animal manure), etc. (Sojka et al. 2007; Walker et al. 2010).

There has been disagreement regarding the effects of PAMs on plant growth. The application of PAMs could have positive effects on plant growth. The PAM application generally improves physical soil parameters such as hydraulic properties, infiltration rate, aeration, root penetration, and aggregate stability, thereby boosts plant establishment and growth rate (Martin 1953; Rubio et al. 1992; Flanagan et al. 2003). PAMs can also preserve plant-available water in soils so as to maintain sufficient soil moisture (Nadler and Steinberger 1993), thus increase water use efficiency and reduce water stress during drought events. Positive effects of PAMs on crop yields and growth activities can be found in Martin (1953), Bjorneberg et al. (2003), Abu-Zreig et al.(2007) and Lentz and Sojka (2009), etc.

Conversely, PAM application could also block the physiological activities of plant growth. Specifically, PAMs can clog pores in soil aggregate surfaces because of their high viscosity and molecular weight (Malik and Letey 1992). The generation of a sealed surface layer resulting from the action of viscous PAMs may subsequently impede plant root respiration and microbial aerobic activities (Letey 1996). High anionic charges can also reduce the mobility of negatively charged soil bacteria and soluble substrates by binding them to the soil aggregates (Sojka et al. 2006). Additionally, as PAMs conserve plant-available water within the soil aggregation, competition for water between PAM molecules and plant roots may be induced when soil moisture is lower than plants demand (Letey et al. 1992). The balance of the competition primarily depend on the soil water content (SWC), soil texture, transpirational pull forces of the plants, and the electrical forces of PAMs. Whatever the results, the plants would be affected by the competition and try to compensate by allocating more energy belowground to strengthen root activities and maintain normal growth. Decreased cone indices and soil microorganism activities have already been reported (Sojka et al. 2006; Busscher et al. 2009). As a result, the response of plants to PAM application is currently unknown.

The effects of PAMs on plant growth may occur at two timescales. The shorter timescale includes the instantaneous processes of $\mathrm{CO}_{2}$ assimilation, $\mathrm{C}$ allocation in various plant organs, respiration and rhizodeposition (Werth and Kuzyakov 2008). While the longer scale includes the accumulation of aboveand below-ground biomass during the entire growth period, and actually represents the cumulative effects of the shorter process-related timescale. The shorter scale has been considered more straightforward and fundamental for the quantification of the instantaneous or cumulative fluxes of photosynthetic and respiratory activities of plant growth (Meharg and Killham 1990; Kuzyakov and Gavrichkova 2010). The integrative analysis of plant growth under the two timescales might provide helpful information on the reactions or mechanisms the plants are involved in.

The ${ }^{14} \mathrm{C}$ isotope is a valuable tracer for monitoring the physiological activities of plant, especially around the root-soil interface (Meharg and Killham 1990; Kuzyakov and Domanski 2000). Compared to other physiological techniques, the isotopic technique is more robust to explore quantitatively and sensitively the dynamics and relationships between different pools of soil-root complex, and to distinguish between different parts of biogenic signals among roots, residuals and soil microorganisms (Kuzyakov and Gavrichkova 2010).

In this study, the two timescales of plant growth were combined to explore the growth of maize under differing PAM treatments. The shoot and root biomass was used to reflect the cumulative effects of PAM on the plants, while the ${ }^{14} \mathrm{C}$ labeling and chasing techniques were employed to trace the effects of 
PAM application on assimilation and allocation activities of $\mathrm{C}$ within the plant-soil system.

\section{Materials and methods}

\section{Soil}

Loess originated from a depth of $15 \mathrm{~m}$ below the present soil surface was used in this study. The loess was taken from an open cast mine at Nussloch (SW Germany, see Bente and Loscher (1987)). We used loess instead of soil because it contains a very low amount of organic $\mathrm{C}$ (about $3 \mathrm{mg} \mathrm{g}^{-1}$ ). Besides, loess has very good physical and chemical properties for root growth and can hold high amount of water (up to $35 \%$ of its weight). The loess contains $29 \% \mathrm{CaCO}_{3}$ and has a $\mathrm{pH}\left(\mathrm{CaCl}_{2}\right)$ of 8.1 . The detailed properties of the loess have previously been described by Kuzyakov et al. (2006).

Three hundred grams of air-dried and sieved $(<2 \mathrm{~mm})$ loess was placed into narrow plastic opentop pots of $300 \mathrm{ml}$ volume. The pots were then covered completely with black paper from outside to prevent the growth of moss and algae and ensure that all nutrients applied were utilized solely by plants.

\section{PAM treatments}

The efficacy of PAMs varied primarily with soil texture and moisture, clay mineral composition, physical and chemical properties of the PAMs, and the rates and methods of application (Barvenik 1994; McLaughlin and Bartholomew 2007). The PAM used is one common anionic PAM called SoilFix ${ }^{\circledR}$ (Ciba Chemical Co., Germany), has a linear formation and granular type, has $90 \%$ active ingredient, a molecular weight of $16 \mathrm{Mg} \mathrm{mol}^{-1}$ and a charge density of $30 \%$.

Two PAM rates, $10 \mathrm{~kg} \mathrm{ha}^{-1}$ (PAM-10) and $40 \mathrm{~kg} \mathrm{ha}^{-1}$ (PAM-40), were tested against control pots that contained no PAM (PAM-0). The PAM was dissolved in distilled water, mixed well, and kept in dark for $24 \mathrm{~h}$. After that, $50 \mathrm{ml}$ solution was poured onto the loess surface as first irrigation 4 days before transplantation to allow for complete infiltration. Each PAM-10 and PAM-40 pot received 5.1 and $20.5 \mathrm{mg}$ of granular PAM, reaching a concentration of 0.1 and
$0.4 \mathrm{~g} \mathrm{~L}^{-1}$ (100 and $\left.400 \mathrm{ppm}\right)$ in solution and 16.7 and $67.0 \mathrm{mg} \mathrm{PAM} \mathrm{kg}{ }^{-1}$ in loess, respectively. The PAM solution had a $\mathrm{pH}$ of 7.2.

Maize growth and experimental layout

Maize (Zea maize L.) seeds were soaked in $0.5 \mathrm{mM}$ $\mathrm{CaCl}_{2}$ solution for 2 days, and then pre-germinated for another 3 days. Each pot was planted with one seedling of $2-3 \mathrm{~cm}$ long. To introduce microorganisms, $10 \mathrm{ml}$ of soil extract from a Haplic Luvisol (developed from loess) were added to each pot. The plants were then fertilized with Hoagland nutrient solution (Hoagland and Arnon 1950), which was previously modified by doubling the amounts of $\mathrm{KH}_{2} \mathrm{PO}_{4}$ and $\mathrm{KNO}_{3}$ and omitting the $\mathrm{Ca}\left(\mathrm{NO}_{3}\right)_{2} \cdot 4 \mathrm{H}_{2} \mathrm{O}$ to balance the large amount of $\mathrm{Ca}^{2+}$ ions available from loess $\mathrm{CaCO}_{3}$ (Gocke et al. 2010). The applied nutrient solution had a pH of 5.5 and contained 138, 62 and $469 \mu \mathrm{g} \mathrm{ml}^{-1}$ of N, P and K, respectively. All plants were grown in a growth chamber with constant temperature of $22^{\circ} \mathrm{C}\left( \pm 0.5^{\circ} \mathrm{C}\right)$, using fluorescent lamp as light source. The day/night period was $14 / 10 \mathrm{~h}$, and light intensity was $800 \mu \mathrm{mol} \mathrm{m} \mathrm{m}^{-2} \mathrm{~s}^{-1}$.

Considering the water-dependent characteristics of PAM, this study was conducted at three rates of soil moisture: 30, 60 and $90 \%$ of the water holding capacity (WHC) (the loess WHC equals $28 \%$ of dry weight). Each day, the water consumption was monitored gravimetrically and the SWC was maintained with equal amounts of nutrient solution, plus distilled water to compensate for the rest of the water loss. This assured the same amounts of nutrient solution, but different amounts of water depending on consumption for each pot of the study period. All plants grew at $70 \%$ soil moisture in the beginning, and were brought under designated levels of soil moisture (i.e. 30, 60 and 90\% of WHC) 5 days before ${ }^{14} \mathrm{C}$ labeling.

To test whether the effects of PAM altered as maize grew, maize age was included as a third factor, and completely crossed over with PAM and SWC treatments. Three age levels were established as groups; each contained the same water and PAM treatments, received the same amount of nutrients and was labeled separately. The three groups were maintained for 19, 24, and 29 days, respectively, and were 
sampled $24 \mathrm{~h}$ after each labeling (Fig. 1). The sampling time was based on the period required for the maize to allocate the new assimilated $\mathrm{C}$ belowground and partly release as exudation (Domanski et al. 2001), but before most part of the released ${ }^{14} \mathrm{C}$ substances were decomposed by microorganisms (Werth and Kuzyakov 2006). The ${ }^{14} \mathrm{C}$ activities recovered in maize represented the net flux between the photosynthetic fixation and plant respiration, under different combinations of the treatments, and thus could be used to evaluate the short-term effects of the PAM application.

To sum up, the entire experimental layout included three fixed factors: three levels of PAM treatments $(0$, $10,40 \mathrm{~kg} \mathrm{ha}^{-1}$, designated PAM-0, PAM-10 and PAM40 , respectively), three soil moisture levels $(30,60$ and $90 \%$ of $\mathrm{WHC}$, designated $\mathrm{W} 30, \mathrm{~W} 60$ and $\mathrm{W} 90$, respectively), and three groups for different growth ages and labelings (20, 25, and 30 days after sowing, designated Day20, Day25 and Day30, respectively) (Fig. 1). The three factors crossed completely, with four pots being randomly assigned to each treatment as replicates, resulting in a common factorial design of 108 pots.

${ }^{14} \mathrm{C}$ labeling and sampling

Maize plants from the same group were labeled simultaneously in an airtight chamber. The label, which consisted of $111 \mathrm{kBq}$ of ${ }^{14} \mathrm{C}$ as $\mathrm{Na}_{2}{ }^{14} \mathrm{CO}_{3}$ (ARC Inc., USA, equal to $6.66 \times 10^{6} \mathrm{DPM}$ per plant pot), was diluted with $10 \mathrm{ml}$ of de-ionized water in a
$30 \mathrm{ml}$ vial. Previously, the water was slightly alkalinized by adding $100 \mu \mathrm{l}$ of $1 \mathrm{M} \mathrm{NaOH}$ to prevent loss of ${ }^{14} \mathrm{C}$ activity by exchange with atmospheric $\mathrm{CO}_{2}$. After connecting the output of the label solution vial to the label chamber, ${ }^{14} \mathrm{CO}_{2}$ was released by injecting $3 \mathrm{ml}$ of $5 \mathrm{M} \mathrm{H}_{2} \mathrm{SO}_{4}$ to the label solution, and was immediately pumped through the chamber for $5 \mathrm{~min}$ using a membrane pump. The plants were kept in the chamber for $4 \mathrm{~h}$ to allow for complete assimilation of the ${ }^{14} \mathrm{CO}_{2}$, after that the air in the chamber was pumped through $15 \mathrm{ml}$ of $1 \mathrm{M} \mathrm{NaOH}$ to trap the unassimilated $\mathrm{CO}_{2}$. The chamber was then removed and the plants were moved back to previous conditions and grew for $24 \mathrm{~h}$ before harvesting.

The shoots were cut from the harvested replicates and weighed, while the roots were separated from the soil with tweezers. After carefully shaking the roots, some soil still adhered; then, the roots were washed with $80 \mathrm{ml}$ of slightly alkalinized distilled water to remove the dissolved inorganic and organic carbon (DIC and DOC) in the remaining soil. The rootwashing water, containing the soil that was directly adhered to the roots (hereafter referred to as rhizosphere soil), was filtered in a stainless steel pressure filter holder (SM 16249, Sartorius, Germany) to recover the solution using a vacuum pump. Five grams of well mixed non-rhizosphere soil (bulk soil) was incubated with $20 \mathrm{ml}$ of $\mathrm{K}_{2} \mathrm{SO}_{4}$ solution for $1 \mathrm{~h}$, after that, the DOC was recovered by centrifugation. Both the shoots and roots were dried at $60^{\circ} \mathrm{C}$, weighed and then grounded in a ball mill (MM200, Retsch, Germany).

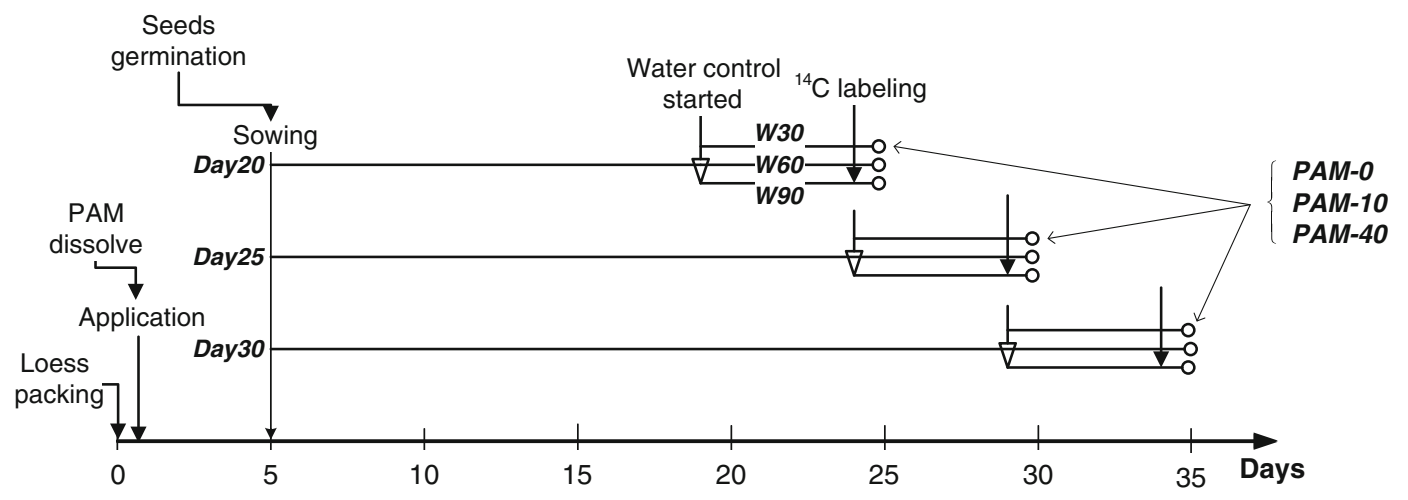

Fig. 1 Schematic timeline of the experimental design, which is a balanced factorial crossover for PAM, SWC, and maize age. The symbols for groups Day25 and Day30 were erased for simplicity. Each open circle contains three PAM treatments (PAM-0, PAM-10 and PAM-40), with four replicates in each PAM treatment 
${ }^{14} \mathrm{C}$ sample analysis

After labeling, the residual ${ }^{14} \mathrm{C}$ activities of the $\mathrm{Na}_{2}{ }^{14} \mathrm{CO}_{3}$ label solution (i.e. the unreleased ${ }^{14} \mathrm{C}$ ) and the ${ }^{14} \mathrm{CO}_{2}$ trapped in the $\mathrm{NaOH}$ after labeling (the unassimilated ${ }^{14} \mathrm{C}$ ) were measured in $1 \mathrm{ml}$ aliquots mixed with $2 \mathrm{ml}$ of scintillation cocktail (Rotiszint EcoPlus, Carl Roth, Germany) after decay of chemiluminescence. The ${ }^{14} \mathrm{C}$ measurements were conducted using a 1450 LSC \& Luminescence Counter (MicroBeta TriLux, Perkin Elmer Inc., USA). The

${ }^{14} \mathrm{C}$ counting efficiency was at least $70 \%$, and the measurement error did not exceed $3.5 \%$. The absolute ${ }^{14} \mathrm{C}$ activity was standardized by external standards by adding increasing amounts of $\mathrm{NaOH}$ as a quencher.

To analyze the ${ }^{14} \mathrm{C}$ incorporated into the plant biomass, $50 \mathrm{mg}$ of grounded shoots or roots powder were combusted in an oven (Feststoffmodul 1300, AnalytikJena, Germany). The $\mathrm{CO}_{2}$ released by combustion was trapped in $10 \mathrm{ml}$ of $1 \mathrm{M} \mathrm{NaOH}$, after that the ${ }^{14} \mathrm{C}$ activity of the $\mathrm{NaOH}$ and the rhizosphere and bulk soil extracts were measured in $1 \mathrm{ml}$ aliquots as described above.

\section{Statistics}

The ${ }^{14} \mathrm{C}$ budgets were carried out for the three labelings separately by subtracting the unassimilated and unreleased ${ }^{14} \mathrm{C}$ activities from the total ${ }^{14} \mathrm{C}$ inputs, and the ${ }^{14} \mathrm{C}$ activities in different pools were recovered and expressed as percentages of the total ${ }^{14} \mathrm{C}$ input if not specified. All data were subjected to non-parametric Shapiro-Wilk test for normality (Shapiro and Wilk 1965). As most variables passed the normality test, no data transformation was conducted to preserve the original data structure. Since no interaction was found between the effect of SWC or maize age with that of PAM application, we conducted Tukey's Honest Significant Differences (HSD) tests (Steel et al. 1997) to evaluate the marginal means of each factor and the effects of PAM treatments in all combinations of age and SWC treatments. All significance level was 0.05 (equivalent to $5 \%$ error probability) unless otherwise specified. Statistical analyses were conducted using R (R Development Core Team 2009) and associate packages.

\section{Results}

Maize growth

All the maize had developed 5-7 leaves at harvest, depending on the growth period. Each pot in the three age groups (Day20, Day25 and Day30) received 70, 90 , and $110 \mathrm{ml}$ of nutrient solution, respectively. The daily water consumption increased during plant growth, and was significantly affected by low SWC (i.e. W30), but did not differ among PAM levels (Table 1), indicating that PAM application had no effect on water consumption of maize.

The three-way factorial ANOVAs showed that PAM application did not affect any of the variables evaluated (Table 2). Except the age by SWC interaction, the interactions among PAM, plant age and SWC were not significant (Table 2). Both the shoot and root biomass increased with age and were significantly affected by SWC (Table 3). Compared with the control, the shoot and root biomass in pots treated with 10 or $40 \mathrm{~kg} \mathrm{ha}^{-1}$ of PAM slightly increased, but the increases were not significant (Table 3 ). The root to shoot ratio ( $\mathrm{R} / \mathrm{S}$ ratio) tended to decrease as plant grew, but significant difference existed only between Day25 and Day30. The shoot water content declined significantly in W30 compared with W60 and W90. The effects of PAM on both the R/S ratio and shoot water content were not significant (Table 3). Within

Table 1 Average Water consumption ( $\mathrm{ml} \mathrm{day}^{-1} \operatorname{pot}^{-1}$ ) in the three factors of the experiment

${ }^{\mathrm{a}}$ The water in the nutrient solution was not included as water consumption. Each figure represent means of 36 pots $(n=36)$; Significant figures were bolded for clarity

${ }^{\mathrm{b}}$ Common letters within the same factor under the same water control stage were not distinct in Tukey's HSD test $(\alpha=0.05)$

\begin{tabular}{llr}
\hline & \multicolumn{2}{l}{ Water control } \\
\cline { 2 - 3 } & Before & After \\
\hline Age & & \\
Day20 & $\mathbf{6 . 4 4}^{\mathrm{a}} \mathbf{c}^{\mathrm{b}}$ & $\mathbf{9 . 2 5} \mathbf{b}$ \\
Day25 & $\mathbf{7 . 2 3 b}$ & $11.03 \mathrm{a}$ \\
Day30 & $\mathbf{8 . 1 1 a}$ & $11.67 \mathrm{a}$ \\
PAM & & \\
PAM-0 & $7.3 \mathrm{a}$ & $10.26 \mathrm{a}$ \\
PAM-10 & $7.11 \mathrm{a}$ & $10.94 \mathrm{a}$ \\
PAM-40 & $7.38 \mathrm{a}$ & $10.74 \mathrm{a}$ \\
SWC & & \\
W30 & - & $\mathbf{9 . 4 5 b}$ \\
W60 & - & $11.08 \mathrm{a}$ \\
W90 & - & $11.42 \mathrm{a}$ \\
\hline
\end{tabular}


Table $2 F$ ratios of the ANOVA for the effects of plant age groups (A), soil water content $(\mathrm{W})$ and PAM(P) on biomass, ${ }^{14} \mathrm{C}$ assimilation and allocation and other related variables

ns not significant; significant items were bolded for clarity $* * * p<0.001, * * p<0.01$, $* p<0.05$

\begin{tabular}{|c|c|c|c|c|c|c|c|}
\hline & Age & SWC & PAM & $\mathrm{A}: \mathrm{W}$ & $\mathrm{A}: \mathrm{P}$ & $\mathrm{W}: \mathrm{P}$ & $A: W: P$ \\
\hline \multicolumn{8}{|l|}{ Plant biomass } \\
\hline Shoot & $142.84 * * *$ & $28.19 * * *$ & $0.66 \mathrm{~ns}$ & $12.27 * * *$ & $0.24 \mathrm{~ns}$ & $2.42 \mathrm{~ns}$ & $1.3 \mathrm{~ns}$ \\
\hline Root & $37.35 * * *$ & $10.13 * * *$ & $0.04 \mathrm{~ns}$ & $4.85 * *$ & $0.56 \mathrm{~ns}$ & $0.2 \mathrm{~ns}$ & $0.88 \mathrm{~ns}$ \\
\hline Maize total & $72.82 * * *$ & $17.33 * * *$ & $0.17 \mathrm{~ns}$ & $7.85 * * *$ & $0.44 \mathrm{~ns}$ & $0.46 \mathrm{~ns}$ & $0.96 \mathrm{~ns}$ \\
\hline $\mathrm{R} / \mathrm{S}$ ratio & $4.27 *$ & $0.18 \mathrm{~ns}$ & $0.41 \mathrm{~ns}$ & $0.84 \mathrm{~ns}$ & $0.96 \mathrm{~ns}$ & $1.21 \mathrm{~ns}$ & $1.27 \mathrm{~ns}$ \\
\hline Shoot water content & $3.1 \mathrm{~ns}$ & $67.43 * * *$ & $0.11 \mathrm{~ns}$ & $3.93 * *$ & $0.05 \mathrm{~ns}$ & $0.26 \mathrm{~ns}$ & $0.36 \mathrm{~ns}$ \\
\hline \multicolumn{8}{|l|}{ Plant ${ }^{14} \mathrm{C}$} \\
\hline Shoot & $4.34 *$ & $28.75 * * *$ & $0.75 \mathrm{~ns}$ & $8.94 * * *$ & $1.09 \mathrm{~ns}$ & $2.08 \mathrm{~ns}$ & $0.8 \mathrm{~ns}$ \\
\hline Root & $5.25 * *$ & $10.58 * * *$ & $1.05 \mathrm{~ns}$ & $8.17 * * *$ & $0.31 \mathrm{~ns}$ & $0.23 \mathrm{~ns}$ & $1.03 \mathrm{~ns}$ \\
\hline Maize total & $4.55 *$ & $31.31 * * *$ & $0.38 \mathrm{~ns}$ & $11.06 * * *$ & $0.76 \mathrm{~ns}$ & $1.88 \mathrm{~ns}$ & $0.78 \mathrm{~ns}$ \\
\hline $\mathrm{R} / \mathrm{S}$ ratio & $3.99 *$ & $3.23 *$ & $1.2 \mathrm{~ns}$ & $1.87 \mathrm{~ns}$ & $0.96 \mathrm{~ns}$ & $0.53 \mathrm{~ns}$ & $0.63 \mathrm{~ns}$ \\
\hline \multicolumn{8}{|l|}{ Soil ${ }^{14} \mathrm{C}$} \\
\hline Rhizosphere DOC & $3.62 *$ & $3.31 *$ & $0.31 \mathrm{~ns}$ & $3.24 *$ & $0.89 \mathrm{~ns}$ & $0.79 \mathrm{~ns}$ & $0.74 \mathrm{~ns}$ \\
\hline Bulk soil DOC & $9.69 * * *$ & $3.96^{*}$ & $0.06 \mathrm{~ns}$ & $0.26 \mathrm{~ns}$ & $1.19 \mathrm{~ns}$ & $0.2 \mathrm{~ns}$ & $0.74 \mathrm{~ns}$ \\
\hline \multicolumn{8}{|l|}{ Total } \\
\hline Total soil ${ }^{14} \mathrm{C}$ & $9.14 * * *$ & $1.94 \mathrm{~ns}$ & $0.02 \mathrm{~ns}$ & $1.1 \mathrm{~ns}$ & $1.07 \mathrm{~ns}$ & $0.02 \mathrm{~ns}$ & $0.86 \mathrm{~ns}$ \\
\hline Total Belowground ${ }^{14} \mathrm{C}$ & $8.03 * * *$ & $7.92 * * *$ & $0.92 \mathrm{~ns}$ & $8.83 * * *$ & $0.21 \mathrm{~ns}$ & $0.21 \mathrm{~ns}$ & $1.35 \mathrm{~ns}$ \\
\hline Total assimilated ${ }^{14} \mathrm{C}$ & $5.31 * *$ & $30.4 * * *$ & $0.37 \mathrm{~ns}$ & $11.23 * * *$ & $0.82 \mathrm{~ns}$ & $1.83 \mathrm{~ns}$ & $0.83 \mathrm{~ns}$ \\
\hline
\end{tabular}

each age level, the shoot and root biomass increased with SWC, but did not differ among the three PAM treatments within each combination of age and SWC (Fig. 2).

New assimilated carbon $\left({ }^{14} \mathrm{C}\right)$

The total ${ }^{14} \mathrm{C}$ assimilation efficiencies were $78.2 \%$, $71.1 \%$ and $64.3 \%$ in Day20, Day25 and Day30, respectively, and were $55.1 \%, 70.2 \%$ and $88.2 \%$ in W30, W60 and W90, respectively. Significant differences in the total ${ }^{14} \mathrm{C}$ assimilation efficiency were observed only between SWC treatments, indicating strong impacts of water stress on $\mathrm{C}$ assimilation. Of the assimilated ${ }^{14} \mathrm{C}$, about $90-99 \%$ was allocated in the plants, and the rest in the soil (rhizosphere and bulk soil). Within each age group, the ${ }^{14} \mathrm{C}$ distribution between shoots and roots primarily corresponded to

Table 3 Tukey's HSD tests of the plant biomass, R/S ratio and shoot water content depending on the three factors

\begin{tabular}{|c|c|c|c|c|c|c|c|c|c|}
\hline & \multicolumn{3}{|l|}{ Age } & \multicolumn{3}{|c|}{ Soil Water Content } & \multicolumn{3}{|l|}{ PAM } \\
\hline & Day20 & Day25 & Day30 & W30 & W60 & W90 & PAM-0 & PAM-10 & PAM-40 \\
\hline Shoot (g) & $0.68^{\mathrm{a}} \mathrm{c}^{\mathrm{b}}$ & $1.02 b$ & $1.36 \mathrm{a}$ & $0.85 b$ & $1.1 \mathrm{a}$ & $1.12 \mathrm{a}$ & 1a & $1.02 \mathrm{a}$ & $1.05 \mathrm{a}$ \\
\hline Root $(g)$ & $1.05 \mathrm{c}$ & $1.61 b$ & $1.9 \mathrm{a}$ & $1.26 b$ & $1.67 \mathrm{a}$ & $1.63 \mathrm{a}$ & $1.5 \mathrm{a}$ & $1.52 \mathrm{a}$ & $1.54 \mathrm{a}$ \\
\hline Total (g) & $1.74 \mathrm{c}$ & $2.63 b$ & $3.27 \mathrm{a}$ & $2.11 b$ & $2.77 \mathrm{a}$ & $2.75 \mathrm{a}$ & $2.5 \mathrm{a}$ & $2.55 \mathrm{a}$ & $2.58 \mathrm{a}$ \\
\hline $\mathrm{R} / \mathrm{S}$ ratio & $1.55 \mathrm{ab}$ & $1.59 \mathrm{a}$ & $1.4 \mathrm{~b}$ & $1.51 \mathrm{a}$ & $1.53 \mathrm{a}$ & $1.49 \mathrm{a}$ & $1.53 \mathrm{a}$ & $1.52 \mathrm{a}$ & $1.48 \mathrm{a}$ \\
\hline Shoot water content $(\%)$ & $85.5 \mathrm{a}$ & $84.5 \mathrm{a}$ & $85 a$ & $82.4 b$ & $86.2 \mathrm{a}$ & $86.5 \mathrm{a}$ & $85.1 \mathrm{a}$ & $85 a$ & $84.9 \mathrm{a}$ \\
\hline
\end{tabular}

${ }^{\mathrm{a}}$ Means are based on 12 pots under the same factor $(n=12)$; Significant figures were bolded for clarity

${ }^{\mathrm{b}}$ For each variable, common letters within the same factor were not distinct in Tukey's HSD test $(\alpha=0.05)$ 
Fig. 2 The distribution of shoots and roots biomass in maize. The shoot and root biomass among the three PAM levels within all age and SWC combinations were not distinct in Tukey's HSD test $(\alpha=0.05)$. Error bars indicate $+1 \mathrm{SE}(n=4)$

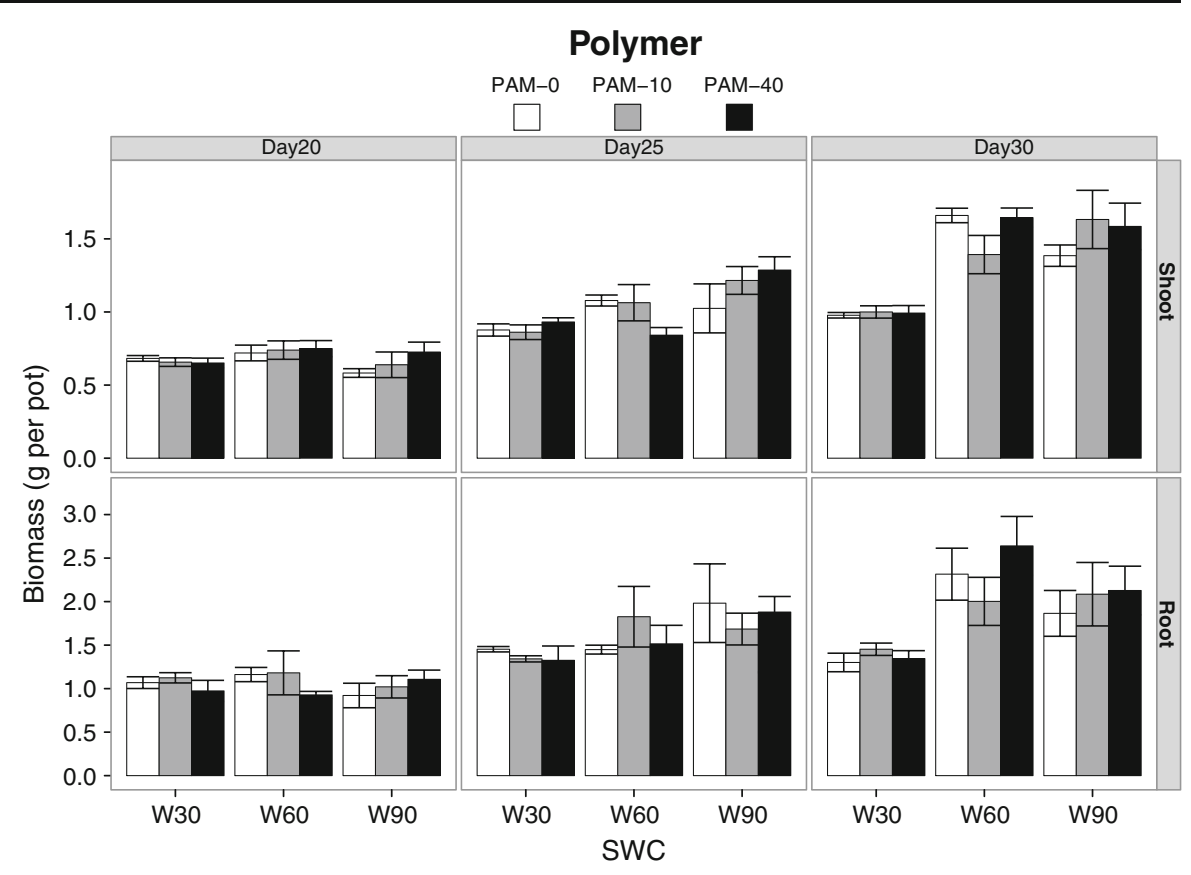

their biomass, and were affected by SWC and plant age, but not by PAM (Figs. 2, 3a,b). Compared with PAM-0, the ${ }^{14} \mathrm{C}$ assimilation by plants showed slight increase but were not statistically significant for PAM-10 and PAM-40. Tukey's HSD tests of the ${ }^{14} \mathrm{C}$ allocation in maize revealed no significant difference of PAM treatments within each combination of SWC and maize age (Fig. 3a,b).

\section{PAM effects on rhizodeposition}

On average $2.36 \%$ of the total assimilated ${ }^{14} \mathrm{C}$ were recovered in the soil, and was significantly distinct only in Day30 (Table 4). The ${ }^{14} \mathrm{C}$ in DOC of the rhizosphere and of bulk soil showed distinct pattern within the three factors, and was significantly affected by age and SWC, but not by PAM (Table 4). The total ${ }^{14} \mathrm{C}$ translocated belowground were closely related to that of ${ }^{14} \mathrm{C}$ in the roots, and showed about 0.6 and $1.3 \%$ decrease in PAM-10 and PAM-40, respectively, compared to that in the control (Table 4).

The ${ }^{14} \mathrm{C}$ in DOC of rhizosphere and bulk soil varied within each level of maize age (Fig. 3c,d). The ${ }^{14} \mathrm{C}$ amount in rhizosphere DOC mainly corresponded to that in root part, but in bulk soil the ${ }^{14} \mathrm{C}$ decreased with maize age (Fig. 3c,d).

\section{Discussion}

The efficacy of PAM application on maize growth

The application of 10 and $40 \mathrm{~kg} \mathrm{ha}^{-1}$ of one common anionic PAM had no significant effects on water consumption, shoot and root biomass, assimilation and allocation of ${ }^{14} \mathrm{C}$ in maize and soil after incubation for a period of 20-30 days. Higher rates of PAM might have had stronger effects as frequently showed in other studies, because higher application rate provides more ion charges that contribute to the flocculation processes, thus improve the soil structure and WHC (Levy et al. 1995; Abu-Zreig et al. 2007). However, in common agricultural practices, PAMs are applied at rates of 1 to $100 \mathrm{~g} \mathrm{~m}^{-3}$ in furrow irrigation water, corresponding to $1-100 \mathrm{~kg}$ dry PAM per hectare (Sojka et al. 2007; Entry et al. 2008). Ten kilograms per hectare has been recommended as standard rate for widespread application that could provide balanced effects in terms of economic, environmental and food-safety considerations, and higher rates $\left(>100 \mathrm{~kg} \mathrm{ha}^{-1}\right)$ are not recommended (Natural Resources Conservation Service 2001; Sojka et al. 2007; Lentz and Sojka 2009). Additionally, due to chemical composition, high input of PAM also 
Fig. 3 The distribution of

${ }^{14} \mathrm{C}$ activities in shoot (a), root (b), rhizosphere DOC (c), and bulk soil DOC (d). The ${ }^{14} \mathrm{C}$ activities among the three PAM levels within all age and SWC combinations were not distinct in Tukey's HSD test $(\alpha=0.05)$. Error bars indicate $+1 \mathrm{SE}(n=4)$

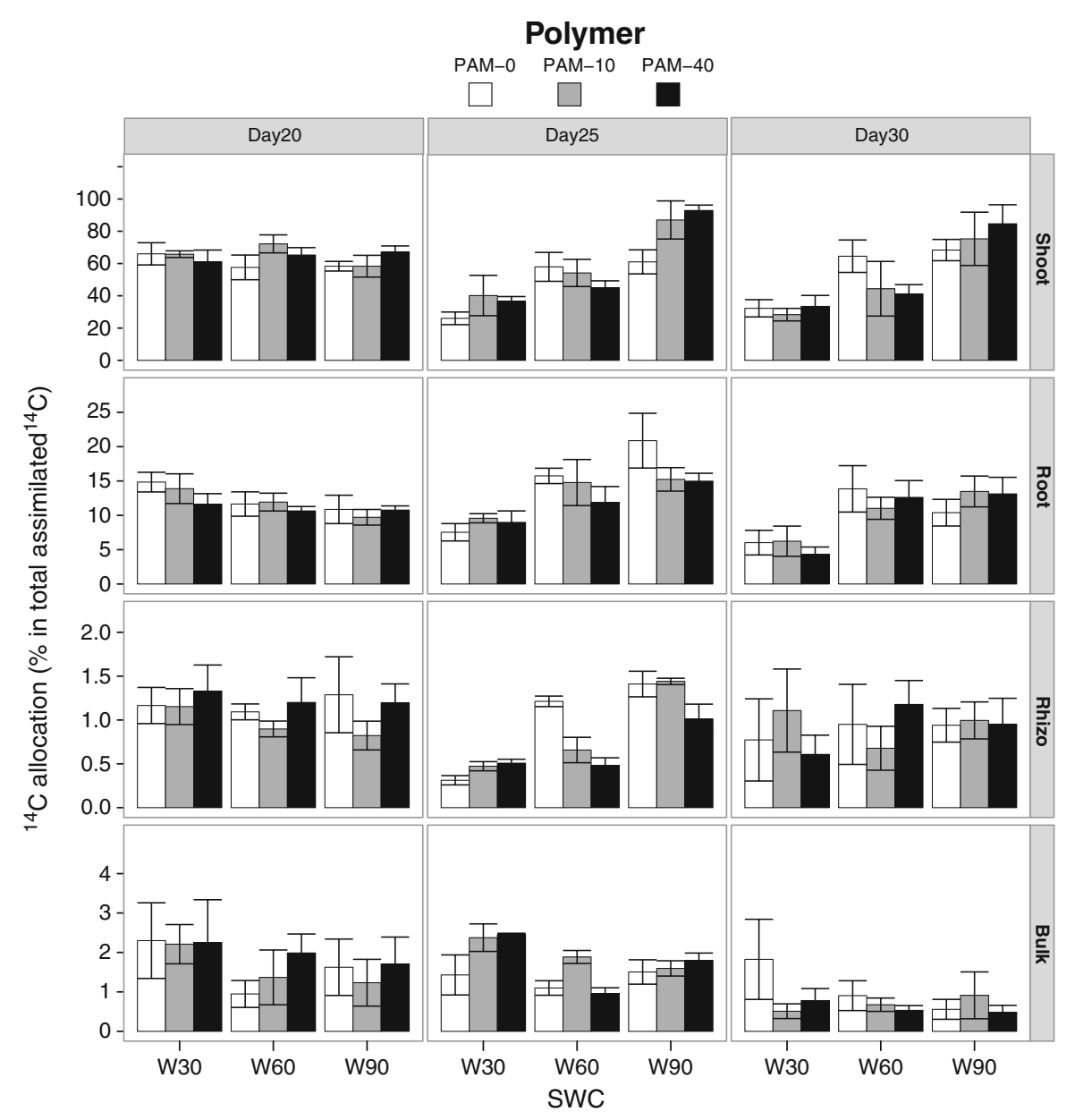

introduces extra $\mathrm{C}$ and $\mathrm{N}$, thus changes the soil nutrient condition as well as activities and composition of microorganisms upon PAM degradation (Kay-Shoemake et al. 1998; Sojka et al. 2006).

As the incubation periods for the PAM in the loess were only 20-30 days, a longer incubation period might be able to bring better resolution. When longer time is adopted, there would be more root extrudes in forms of mineral particles and organic materials, which act as granulating agents and could accelerate the interactions between the clay particles and PAM chains (Martin 1953; Lentz and Bjorneberg 2003). However, the aggregation procedure mediated by PAM takes place quite fast, i.e. within a few days or even hours after the PAM is applied (Green and Stott 1999), which means the efficacy of PAM might not be dependent on the duration of our study.
The efficacy of PAM could be largely influenced by the loess used in the experiment. There's evidence that soil with high clay or silt content and low organic matter content had high absorptive affinity of anionic PAM, and the sorption increased as the increase of total dissolved salts (Sojka et al. 2007). The loess used has high silt composition, low organic matter content, and high divalent $\mathrm{Ca}^{2+}$ ions, and should be sensitive to PAM application. However, there is also property that made the loess inert to the application. The loess has no structure, and thus is not aggregated at all. As the capacity of PAM is to "improve" existing structures, not to "build" new (Sojka et al. 2007), the effects of PAM, if any, could be masked due to a lack of basal aggregation. Unfortunately, as soil types were not included in the current experiment, this explanation cannot be testified here. 
Table 4 Tukey's HSD test of the ${ }^{14} \mathrm{C}$ distribution in plant and soil depending on the three factors

\begin{tabular}{|c|c|c|c|c|c|c|c|c|c|}
\hline & \multicolumn{3}{|l|}{ Age } & \multicolumn{3}{|c|}{ Soil water content } & \multicolumn{3}{|l|}{ Polymer } \\
\hline & Day20 & Day25 & Day30 & W30 & W60 & W90 & PAM-0 & PAM-10 & PAM-40 \\
\hline Shoot $(\%)$ & $63.5^{\mathrm{a} a}$ & $55.4 \mathrm{a}$ & $52.5 \mathrm{a}$ & $43.3 \mathrm{c}$ & $55.6 \mathrm{~b}$ & $72.6 a$ & $54.4 \mathrm{a}$ & $58.4 \mathrm{a}$ & $58.6 \mathrm{a}$ \\
\hline Root $(\%)$ & $11.8 \mathrm{ab}$ & $13.2 \mathrm{a}$ & $10.1 b$ & $9.2 \mathrm{~b}$ & $12.6 \mathrm{a}$ & $13.3 \mathrm{a}$ & $12.3 \mathrm{a}$ & $11.8 \mathrm{a}$ & $11 \mathrm{a}$ \\
\hline Total $(\%)$ & $75.3 \mathrm{a}$ & $68.6 \mathrm{a}$ & $62.6 \mathrm{a}$ & $52.5 \mathrm{c}$ & $68.2 b$ & $85.8 \mathrm{a}$ & $66.7 \mathrm{a}$ & $70.2 \mathrm{a}$ & $69.6 \mathrm{a}$ \\
\hline $\mathrm{R} / \mathrm{S}$ ratio & $0.19 b$ & $0.27 \mathrm{a}$ & $0.23 \mathrm{ab}$ & $0.24 \mathrm{ab}$ & $0.26 \mathbf{a}$ & $0.19 b$ & $0.24 \mathrm{a}$ & $0.24 \mathrm{a}$ & $0.2 \mathrm{a}$ \\
\hline Rhizosphere DOC (\%) & $1.13 \mathrm{a}$ & $0.82 b$ & $0.91 \mathrm{ab}$ & $0.83 b$ & $0.92 \mathrm{ab}$ & $1.12 \mathrm{a}$ & $1.01 \mathrm{a}$ & $0.91 \mathrm{a}$ & $0.94 \mathrm{a}$ \\
\hline Nonrhizo-DOC (\%) & $1.74 \mathrm{a}$ & $1.69 \mathrm{a}$ & $0.8 b$ & $1.79 a$ & $1.15 b$ & $1.27 \mathrm{ab}$ & $1.36 \mathrm{a}$ & $1.42 \mathrm{a}$ & $1.44 \mathrm{a}$ \\
\hline Total soil ${ }^{14} \mathrm{C}(\%)$ & $2.86 \mathrm{a}$ & $2.51 \mathrm{a}$ & $1.71 \mathrm{~b}$ & $2.62 \mathrm{a}$ & $2.07 \mathrm{a}$ & $2.39 \mathrm{a}$ & $2.37 \mathrm{a}$ & $2.33 \mathrm{a}$ & $2.38 \mathrm{a}$ \\
\hline Below ground (\%) & $14.6 \mathrm{ab}$ & $15.7 \mathrm{a}$ & $11.8 \mathrm{~b}$ & $11.8 \mathrm{~b}$ & $14.6 \mathrm{ab}$ & $15.7 \mathrm{a}$ & $14.7 \mathrm{a}$ & $14.1 \mathrm{a}$ & $13.4 \mathrm{a}$ \\
\hline Total assimilated (\%) & $78.2 \mathrm{a}$ & $71.1 \mathrm{a}$ & $64.3 \mathrm{a}$ & 55.1c & $70.2 b$ & $88.2 \mathrm{a}$ & $69.1 \mathrm{a}$ & $72.5 \mathrm{a}$ & $72 \mathrm{a}$ \\
\hline
\end{tabular}

${ }^{\mathrm{a}}$ Means are based on 12 pots under the same factor $(n=12)$. Significant figures were bolded for clarity

${ }^{\mathrm{b}}$ For each variable, common letters within the same factor were not distinct in Tukey's HSD test $(\alpha=0.05)$

In pots treated with PAM, the consistent pattern in the two timescales (biomass and ${ }^{14} \mathrm{C}$ content) suggested positive effects of PAM application on maize growth. In the other studies, Lentz and Sojka (2009) applied PAM at $10 \mathrm{mg} \mathrm{L}^{-1}$ water and found that PAM decreased soil losses by $84 \%$ and prevented the loss of $47.8 \mathrm{Mg}$ soil ha ${ }^{-1}$ over the 7 -yr period. However, only a $4.5 \%$ increase in corn yield was observed. Busscher et al. (2009) applied PAMs in different tillage systems, and found that the PAM treatments were dominated by tillage, and detected no effect in yields after 3 years. After comparing these findings with our results, we argue that the effect of PAM application on yields is rather indirect and subjected to improvements of the soil structure and WHC, and the purpose of yields increase should come after the amendments in structural and hydraulic properties of soil in common agricultural practices.

\section{Dependence of PAM effects on plant age and SWC}

The evaluation of PAM application was conducted together with two other factors, SWC and maize age, both showed significant impacts on water consumption, plant biomass and ${ }^{14} \mathrm{C}$ allocation. In total variations of assimilated ${ }^{14} \mathrm{C}$, about $33 \%$ could be attributed to SWC, $14 \%$ to maize age, and only $3 \%$ to PAM application (Table 4), indicating that the assimilation and allocation of new $\mathrm{C}$ (as ${ }^{14} \mathrm{C}$ ) were primarily dominated by SWC. While the effects of SWC on plant biomass were restricted in W30, its effects on ${ }^{14} \mathrm{C}$ covered all three SWC levels (Tables 3 and 4), indicating that SWC dominated the photosynthesis of maize. Maize age showed significant effects in biomass across the three levels, but insignificant in ${ }^{14} \mathrm{C}$ as compared to SWC (Tables 3 and 4 ). Within each age level, the ${ }^{14} \mathrm{C}$ allocation showed different patterns among the PAM treatments under different SWC levels, e.g. in Day25 and Day30, the shoot ${ }^{14} \mathrm{C}$ in W60 was slightly lower in pots with PAM treatments; while in W90, it was higher (Fig. 3a). Compared to the ${ }^{14} \mathrm{C}$ in shoot and root parts, the ${ }^{14} \mathrm{C}$ in the rhizosphere and bulk soil showed higher variability among PAM treatments under different combinations of SWC and age treatments (Fig. 3c,d), indicating more complex processes been involved in both pools.

The ${ }^{14} \mathrm{C}$ allocation in the three age groups actually represented two $\mathrm{C}$ partition patterns (Fig. 3). In groups Day25 and Day30, ${ }^{14} \mathrm{C}$ allocation was dominated by SWC, with plants in high SWC obtained more ${ }^{14} \mathrm{CO}_{2}$ and allocated more into other pools by proportion. While in group Day20, due to unsuccessful water control, all plants got similar amounts of ${ }^{14} \mathrm{CO}_{2}$, but roots in low SWC could get relatively more $\mathrm{C}$ to participate in the root activities driven by water shortage (Fig. 3). As a result, the effects of PAM application could be SWC and age specific (Gavrich- 
kova and Kuzyakov 2010), and consequently can be related to rhizosphere processes that the PAM and SWC effects were dependent on.

\section{PAM effects and rhizodeposition}

As a complex interface between plant and soil, rhizosphere region plays key roles in the efficacy of PAM. Even though ANOVA tests did not reveal any significant effects of PAM application, it is notable that the $F$ ratios of the fixed effects of PAM were relatively higher in root ${ }^{14} \mathrm{C}$ content (Table 2), indicating that roots might be influenced more directly than other $\mathrm{C}$ pools in the plants or soil. The discernable decrease of ${ }^{14} \mathrm{C}$ in both the roots and rhizosphere DOC in pots treated with PAM might indicate decrease of root activities and could be aroused by the adaptive strategy that the plants used, in which more new assimilated $\mathrm{C}$ was allocated to the shoot to maximize the leaf area ratio for faster growth (Lambers et al. 1998) when PAM was applied. This strategy is favored by the plants given the condition that soil nutrients and plant-available water is enough for the performance of root activities (Werth and Kuzyakov 2006), and the condition is supposed to improve by the application of PAM. As a result, it is reasonable to infer that the PAM application altered the allocation of ${ }^{14} \mathrm{C}$ in maize. But how could the application of PAM in soil influences biomass and ${ }^{14} \mathrm{C}$ allocation?

Two mechanisms can be outlined in order to account for possible effects of PAM on plant growth. The first is that the PAM application increased plantavailable water, extractable $\mathrm{P}$ and $\mathrm{K}$, and microelement levels in soil (Lentz and Sojka 2009). These substances can be gathered together by electrical or van der Waals forces of PAM, participate in the rhizosphere reactions and finally be absorbed by the plants. The second could be that the improved soil properties, such as aeration, root penetration, and water infiltration, etc., contributed to the establishment of maize seedlings and root growth (Rubio et al. 1992). The slight increases in root biomass in the PAM-10 and PAM-40 treatments (Table 3) could at least partially approve this. The discernable increase in total ${ }^{14} \mathrm{C}$ assimilation could also indicate positive influence of PAM on maize roots. This is because plants normally respire more energy when the nutrient or water supply is limited (Werth and Kuzyakov
2006), and increased total assimilation is a reliable surrogate of less respiration consumption.

Actually, as the only pathway for plants being affected by PAM application, the role that the rhizosphere may play could either be direct, which is based on the physiochemical and electrical perspectives of rhizosphere zone, or indirect which relies on the aggregating characteristics around this region. As a result, and due to their age and soil-moisture specific characteristics, the PAM effects might be subjected to more trivial factors that influence the rhizodeposition processes, such as the degradation of labile PAM into ineffective monomers (Entry et al. 2008), the priming effects inspired by the input of ${ }^{14} \mathrm{C}$ label (Kuzyakov and Gavrichkova 2010), the enhanced aggregation process due to the extrusion of inorganic elements and SOMs (Abiven et al. 2009), the disturbance processes between aggregation and seal formation (Shainberg and Levy 1994), as well as the accelerated SWC oscillation driven by the increasing demand for water for plant growth, etc. Because of this fact, and in order to better understand the processes that the PAM is involved in and to evaluate its effects, more intensive spatiotemporal sampling or modeling are required in later studies.

\section{Conclusions}

Two rates (10 and $40 \mathrm{~kg} \mathrm{ha}^{-1}$ ) of an anionic linear polyacrylamide were applied to non-aggregative and high-water-absorbing loess for a period up to 1 month. The effects of PAM on water consumption, biomass accumulation, and $\mathrm{C}$ assimilation and allocation in maize and rhizodeposition in soil were tested. Soil water content and age significantly affected these variables, but none variables were affected by PAM application. The effects of PAM application on maize growth were largely masked by the non-structural loess, tended to be age and soil-moisture specific, and were modulated by the rhizodeposition processes. As a result, the absence of negative effects of PAM on plant growth suggests that the PAM can be applied at least up to $40 \mathrm{~kg} \mathrm{ha}^{-1}$ without notable negative effects on plant growth.

Acknowledgements The authors thank the German Academic Exchange Service (DAAD) and the Chinese Scholarship Council (CSC) for funding of the joint PPP program, which 
enabled L. Wu and X.L. Xu to conduct the experiments in Germany. We thank the Visiting Professorship by the Chinese Academy of Sciences for Y. Kuzyakov to carry on the research in China. Polyacrylamide was supported by the Cooperative Research Program for Agricultural Science \& Technology Development (PJ0074092010) of the RDA in Korea. We would like to acknowledge J. Kettering and Dr. M. Gocke for their help in the experiment. We are also very grateful to Dr. M.H. Song and four anonymous reviewers for their constructive and valuable comments to improve this manuscript.

Open Access This article is distributed under the terms of the Creative Commons Attribution Noncommercial License which permits any noncommercial use, distribution, and reproduction in any medium, provided the original author(s) and source are credited.

\section{References}

Abiven S, Menasseri S, Chenu C (2009) The effects of organic inputs over time on soil aggregate stability - a literature analysis. Soil Biol Biochem 41:1-12

Abu-Zreig M, Al-Sharif M, Amayreh J (2007) Erosion control of arid land in Jordan with two anionic polyacrylamides. Arid Land Res Manag 21:315-328

Barvenik FW (1994) Polyacrylamide characteristics related to soil applications. Soil Sci 158:235-243

Bente B, Loscher M (1987) Sedimentologische, pedologische und stratigraphische Untersuchungen an Lossen sudlich Heidelberg. Gottinger Geographische Abhandlungen 84:9-17

Bjorneberg DL, Santos FL, Castanheira NS, Martins OC, Reis JL, Aase JK, Sojka RE (2003) Using polyacrylamide with sprinkler irrigation to improve infiltration. J Soil Water Conserv 58:283-289

Busscher WJ, Bjorneberg DL, Sojka RE (2009) Field application of PAM as an amendment in deep-tilled US southeastern coastal plain soils. Soil Till Res 104:215-220

Domanski G, Kuzyakov Y, Siniakina SV, Stahr K (2001) Carbon flows in the rhizosphere of ryegrass (Lolium perenne). Journal of Plant Nutrition and Soil ScienceZeitschrift Fur Pflanzenernahrung Und Bodenkunde 164:381-387

Entry JA, Sojka RE, Hicks BJ (2008) Carbon and nitrogen stable isotope ratios can estimate anionic polyacrylamide degradation in soil. Geoderma 145:8-16

Flanagan DC, Norton LD, Peterson JR, Chaudhari K (2003) Using polyacrylamide to control erosion on agricultural and disturbed soils in rainfed areas: advances in the use of polyacrylamide (PAM) for soil and water management. J Soil Water Conserv 58:301-311

Gavrichkova O, Kuzyakov Y (2010) Respiration costs associated with nitrate reduction as estimated by (CO2)-C-14 pulse labeling of corn at various growth stages. Plant Soil 329:433445

Gocke M, Pustovoytov K, Kuzyakov Y (2010) Effect of CO2 concentration on the initial recrystallization rate of pedogenic carbonate - revealed by C-14 and C-13 labeling. Geoderma 155:351-358
Green VS and Stott DE (1999) Polyagrylamide: a review of the use, effectiveness, and cost of a soil erosion control amendment. In The 10th International Soil Conservation Organization Meeting. pp 384-389, Purdue University and the USDA-ARS National Soil Erosion Research Laboratory

Hedrick RM, Mowry DT (1952) Effect of synthetic polyelectrolytes on aggregation, aeration, and water relationships of soil. Soil Sci 73:427-442

Hoagland DR, Arnon DI (1950) The water-culture method for growing plants without soil. Calif Agr Exp Sta 347:1-32

Kay-Shoemake JL, Watwood ME, Lentz RD, Sojka RE (1998) Polyacrylamide as an organic nitrogen source for soil microorganisms with potential effects on inorganic soil nitrogen in agricultural soil. Soil Biol Biochem 30:10451052

Kuzyakov Y, Domanski G (2000) Carbon input by plants into the soil. Review. J Plant Nutr Soil Sc 163:421-431

Kuzyakov Y, Gavrichkova O (2010) Time lag between photosynthesis and carbon dioxide efflux from soil: a review of mechanisms and controls. Global Change Biol 16:3386-3406

Kuzyakov Y, Shevtzova E, Pustovoytov K (2006) Carbonate re-crystallization in soil revealed by $\mathrm{C}-14$ labeling: experiment, model and significance for paleo-environmental reconstructions. Geoderma 131:45-58

Lambers H, Chapin FS, Pons TL (1998) Plant physiological ecology. Springer, Berlin

Lentz RD, Bjorneberg DL (2003) Polyacrylamide and straw residue effects on irrigation furrow erosion and infiltration. J Soil Water Conserv 58:312-319

Lentz RD, Sojka RE (2009) Long-term polyacrylamide formulation effects on soil erosion, water infiltration, and yields of furrow-irrigated crops. Agron J 101:305-314

Letey J (1996) Effective viscosity of PAM solution through porous media. In: Sojka RE, Lentz RD (eds) Managing irrigation-induced erosion and infiltration with polyacrylamide. University of Idaho Misc. Pub., College of Southern Idaho, Twin Falls, ID, pp 94-96

Letey J, Clark PR, Amrhein C (1992) Water-sorbing polymers do not conserve water. Calif Agric 46:9-10

Levy GJ, Levin J, Shainberg I (1995) Polymer effects on runoff and soil-erosion from sodic soils. Irrigation Sci 16:9-14

Malik M, Letey J (1992) Pore-size-dependent apparent viscosity for organic solutes in saturated porous media. Soil Sci Soc Am J 56:1032-1035

Martin WP (1953) Status report on soil conditioning chemicals. I. Soil Sci Soc Am J 17:1-9

McLaughlin RA, Bartholomew N (2007) Soil factors influencing suspended sediment flocculation by polyacrylamide. Soil Sci Soc Am J 71:537-544

Meharg AA, Killham K (1990) Carbon distribution within the plant and rhizosphere in laboratory and field-grown lolium-perenne at different stages of development. Soil Biol Biochem 22:471-477

Nadler A, Steinberger Y (1993) Trends in structure, plantgrowth, and microorganism interrelations in the soil. Soil Sci 155:114-122

Natural Resources Conservation Service (2001) Anionic Polyacrylamide (PAM) erosion control. Conservation Practice Standard 450. Ed. Natural Resources Conservation Service. Washington, DC, pp 1-3 
R Development Core Team (2009) R: a language and environment for statistical computing. R Foundation for Statistical Computing, Vienna

Rubio HO, Wood MK, Cardenas M, Buchanan BA (1992) The effect of polyacrylamide on grass emergence in SouthCentral New-Mexico. J Range Manage 45:296-300

Shainberg I, Levy GJ (1994) Organic polymers and soil sealing in cultivated soils. Soil Sci 158:267-273

Shapiro SS, Wilk MB (1965) An analysis of variance test for normality (complete samples). Biometrika 52:591-611

Sherwood LV, Engibous JC (1953) Status report on soil conditioning chemicals. II. Soil Sci Soc Am J 17:9-16

Sojka RE, Entry JA, Fuhrmann JJ (2006) The influence of high application rates of polyacrylamide on microbial metabolic potential in an agricultural soil. Appl Soil Ecol 32:243252
Sojka RE, Bjorneberg DL, Entry JA, Lentz RD, Orts WJ (2007) Polyacrylamide in agriculture and environmental land management. Adv Agron 92:75-162

Steel RGD, Torri JH, Dickey AD (1997) Principles and procedures of statistics: A biometrical approach. McGraw-Hill, New York

Walker PM, Wade CA, Kelley TR (2010) Evaluation of a polyacrylamide assisted solid/liquid separation system for the treatment of liquid pig manure. Biosyst Eng 105:241246

Werth M, Kuzyakov Y (2006) Assimilate partitioning affects C-13 fractionation of recently assimilated carbon in maize. Plant Soil 284:319-333

Werth M, Kuzyakov Y (2008) Root-derived carbon in soil respiration and microbial biomass determined by $\mathrm{C}-14$ and C-13. Soil Biol Biochem 40:625-637 